\title{
METODE PEMBUATAN ANTIPROLAKTIN PADA HEWAN COBA KAMBING LOKAL SEBAGAI PENGHAMBAT PROSES RONTOK BULU PADA AYAM ARAB PETELUR
}

\author{
Erma Safitri \\ Fakultas Kedokteran Hewan Universitas Airlangga
}

\begin{abstract}
Anti-prolactin has a specific activity against prolactin. It neutralizes prolactin action in circulation. The effect of such neutralization is the inhibition of feather fall off process, so that hens may be able to produce eggs again. Anti-prolactin can be produced by injecting prolactin isolate from blood serum of arabic hens in feather fall off-phase into local goat. Prolactin isolate was immunized to local goat to produce anti-prolactin. Six local goats were divided into 2 groups. The first group comprised 1 goat immunized with PBS, and the second one was immunized with prolactin isolate in CFA and subjected to booster with prolactin isolate in IFA twice. The formation of anti-prolactin and the highest titer was detected using indirect ELISA. The results of this study showed that (1) Anti-prolactin could be produced in goat from the prolactin isolate of feather fall off-phase arabic hens blood serum; (2). The first emergence of Antiprolactin was at the first bleeding after immunization of prolactin isolate in CFA and first booster in IFA. The highest titer was found at eleventh bleeding after the third booster with prolactin isolate in IFA.
\end{abstract}

Key words: antiprolactin, prolactin, arabic hens, feather fall off

\section{PENGANTAR}

Menurut Hafez (2000) dan Knobil et al. (1988), rontok bulu pada seekor ayam disebabkan oleh tingginya kadar hormon prolaktin dalam darah. Hormon prolaktin merupakan hormon protein dengan berat molekul (BM) 24.000-27.000 Da (Yamamoto and Tanaka, 2003; Bedecarrats et al., 1999; March, et al., 1999) dan kandungan asam amino sebanyak 199 (Jabbour and Kelly, 1997). Tingginya kadar hormon prolaktin dalam darah selain dapat menyebabkan terjadinya kerontokan bulu pada ayam petelur ternyata juga dapat menyebabkan terjadinya regresi ovarium, yaitu suatu keadaan di mana tidak terjadinya pertumbuhan folikel pada ovarium sehingga unggas akan berhenti bertelur dalam jangka waktu yang cukup lama (Ramesh et al., 2001).

Prolaktin dapat digolongkan ke dalam bahan yang bersifat imunogen, yaitu suatu bahan yang dapat menyebabkan terbentuknya antibodi jika disuntikkan secara berulang pada hewan coba. Salah satu syarat suatu bahan dapat dikatakan bersifat imunogen jika mempunyai BM yang lebih besar dari $10.000 \mathrm{Da}$, sedangkan prolaktin mempunyai BM 24.000-27.000 Da, sehingga bila disuntikkan secara berulang pada hewan diharapkan dapat menginduksi timbulnya antibodi poliklonal antiprolaktin (antiprolaktin) (Fitzgerald, 2004; Agrisera, 2004; Upstate, 2002). Pemberian antiprolaktin pada seekor ayam yang memasuki fase rontok bulu nantinya diharapkan dapat bekerja secara spesifik terhadap prolaktin dengan cara menetralisasi kerja prolaktin dalam darah, sehingga proses rontok bulu dapat dihambat dan terjadi pertumbuhan folikelfolikel pada ovarium sehingga ayam dapat berproduksi telur kembali secara normal dan alamiah.

Menurut Bell and Kuney (2003) dan Avma (2003) cara untuk mengatasi rontok bulu di United States dan beberapa negara termasuk Indonesia, untuk mengatasi rontok bulu dengan cara pemuasaan dan pembatasan pakan. Cara tersebut biasanya dilakukan selama sekitar 30-60 hari (Sainsbury, 1995; Barton, 2003; Poultry, 2003). Hanya saja penggunaan kedua cara di atas banyak ditentang oleh beberapa organisasi keselamatan dan penyayang binatang seperti United Poultry Concern dan The Association of Veterinarians di United States (Allen, 2002). Organisasi tersebut mengajukan permohonan pada United States Departemen of Agriculture and Food and Drug untuk tidak menggunakan pemuasaan dan pembatasan pakan dalam mengatasi rontok bulu. Hal ini didasari bahwa pemuasaan dan pembatasan pakan dalam waktu lama dapat menyebabkan stres yang berakibat penurunan fungsi imun sehingga ayam mudah terserang penyakit (Alodan and Mashaly, 1999). Salah satu penyakit yang sering mengikuti induksi rontok bulu tersebut adalah Salmonella enteridis (SE) (Poultry, 2003; FACT, 2001; Webster, 1999), oleh karena itu sejak tahun 2000 telah dilarang pembatasan pakan untuk mengatasi rontok bulu (Avma, 2003). Menurut FACT, (2001); dan Webster (1999), SE ini sangat berbahaya, karena bersifat zoonosis. 
Berdasarkan latar belakang di atas, maka penelitian ini ditujukan untuk menghambat proses rontok bulu tanpa menimbulkan penderitaan dan penurunan respons imun pada ayam, yaitu melalui pemberian antiprolaktin. Antiprolaktin ini dapat diproduksi dengan cara menyuntikan isolat prolaktin yang berasal dari serum darah ayam arab fase rontok bulu pada kambing (Agrisera, 2004), sehingga harapan untuk dapat meningkatkan produksi telur dan populasi ayam arab secara cepat dapat terlaksana tanpa menyakiti atau menyiksa dan menurunkan fungsi imunnya.

\section{BAHAN DAN CARA KERJA}

Bahan dalam penelitian ini adalah berupa isolat prolaktin yang didapat dari serum darah ayam arab fase rontok bulu. Serum didapat dengan cara pengambilan darah pada vena axilaris di daerah sayap dari ayam. Selanjutnya darah yang didapat ditampung pada tabung venojack $10 \mathrm{cc}$, kemudian diletakkan miring $45^{\circ}$ dan dibiarkan mengendap pada suhu kamar, selanjutnya dilakukan sentrifuge untuk mendapatkan serum yang dimaksud. Kemudian langkah berikutnya dilakukan purifikasi dengan metoda SAS 50\% (Saturation Amonium Sulfat). Langkah berikutnya untuk mendapatkan isolat prolaktin murni dilakukan juga karakterisasi dengan metoda SDS-PAGE 12\%, uji spesifitas metode Western Bloting dan pemurnian protein metode Electro Elusi yang telah dilakukan pada penelitian sebelumnya. Setelah isolat prolaktin murni didapatkan maka langkah selanjutnya dilakukan pembuatan antiprolaktin pada hewan coba kambing.

\section{Pembuatan Antiprolaktin}

Metode pembuatan antiprolaktin dapat dilakukan dengan imunisasi secara aktif pada hewan coba yaitu dengan cara melakukan beberapa kali penyuntikan pada hewan coba tersebut. Hewan coba yang digunakan dalam penelitian ini adalah kambing lokal jantan yang disuntik secara intra cutan (Goldsby and Osborne, 2000; Biosystem, 1999). Jadwal pembuatan antiprolaktin dapat dilihat pada tabel 1, di mana satu hari sebelum jadwal penyuntikan dilakukan bleeding (pengambilan darah) pre-imun, dengan tujuan untuk membandingkan terbentuk atau tidaknya antiprolaktin serta diketahui kapan waktu mulai terbentuknya antiprolaktin tersebut.

\section{Purifikasi IgG dari Antiprolaktin}

Purifikasi IgG dari antiprolaktin dilakukan dengan penambahan SAS $50 \%$ pada serum kambing dengan perbandingan 1: 1, kemudian dihomogenkan dengan vortexer dan diinkubasi beberapa menit pada suhu $4^{\circ} \mathrm{C}$.
Tabel 1. Jadwal dan prosedur produksi antiprolaktin pada Kambing

\begin{tabular}{|c|c|c|}
\hline Hari & Prosedur & $\begin{array}{l}\text { Adjuvan/ } \\
\text { Keterangan }\end{array}$ \\
\hline-1 & Bleeding pre-imun & - \\
\hline 0 & $\begin{array}{l}\text { Imunisasi pertama }=1 \mathrm{ml} \text { isolat } \\
\text { prolaktin }(350 \mu \mathrm{g} / \mathrm{ml})\end{array}$ & $\mathrm{CFA}=1 \mathrm{ml}$ \\
\hline 12 & $\begin{array}{l}\text { Imunisasi kedua }(\text { Booster I) }=1 \mathrm{ml} \\
\text { isolat prolaktin }(350 \mu \mathrm{g} / \mathrm{ml})\end{array}$ & IFA ke-1 = $1 \mathrm{ml}$ \\
\hline 19 & Bleeding ke-1 & - \\
\hline 26 & Bleeding ke-2 & - \\
\hline 33 & Bleeding ke-3 & - \\
\hline 40 & Bleeding ke-4 & - \\
\hline 43 & $\begin{array}{l}\text { Imunisasi ketiga }(\text { Booster II) }=1 \mathrm{ml} \\
\text { isolat prolaktin }(350 \mu \mathrm{g} / \mathrm{ml})\end{array}$ & IFA ke-2 = $1 \mathrm{ml}$ \\
\hline 50 & Bleeding ke-5 & - \\
\hline 57 & Bleeding ke-6 & - \\
\hline 64 & Bleeding ke-7 & - \\
\hline 71 & Bleeding ke-8 & - \\
\hline 74 & $\begin{array}{l}\text { Imunisasi keempat }(\text { Booster III) }=1 \mathrm{ml} \\
\text { isolat prolaktin }(350 \mu \mathrm{g} / \mathrm{ml})\end{array}$ & IFA ke-3 = $1 \mathrm{ml}$ \\
\hline 81 & Bleeding ke-9 & - \\
\hline 88 & Bleeding ke-10 & - \\
\hline 95 & Bleeding ke-11 & - \\
\hline 102 & Bleeding ke-12 & - \\
\hline
\end{tabular}

Serum disentrifugasi $3000 \mathrm{rpm}$ pada suhu $4{ }^{\circ} \mathrm{C}$ selama 30 menit. Supernatan dibuang, presipitat dicuci dengan SAS $50 \%(10 \times$ volume pelet $)$, kemudian dihomogenkan dengan menggunakan vortex dan disentrifugasi dengan kecepatan $3000 \mathrm{rpm}$ pada suhu $4{ }^{\circ} \mathrm{C}$ selama 30 menit. Presipitat ditambah dengan $0,05 \mathrm{M}$ buffer phosphat $\mathrm{pH} 7$ pada volume $1 \mathrm{ml}$ dimasukkan ke dalam selofan, diberi label, kemudian diikat. Dilanjutkan dialisis dalam 0,01 M buffer fosfat $\mathrm{pH} 7$, semalam pada suhu $4{ }^{\circ} \mathrm{C}$.

\section{Pengukuran Titer Antiprolaktin}

Prosedur kerja ELISA indirect sebagai berikut: Ag (isolat prolaktin) kadar $100 \mathrm{mg} / \mathrm{ml}$ dilarutkan dalam Coating buffe) dimasukkan dalam microplate $50 \mu 1$ tiap sumuran, kemudian diinkubasi pada $4^{\circ} \mathrm{C}$ selama $24 \mathrm{jam}$. Setelah itu dilakukan pencucian dengan $0,05 \%$ PBS-Tween 20 sebanyak4 kali@3 menit dan diblok dengan Blocking buffer sebanyak $50 \mu$ l tiap sumuran, kemudian diinkubasi pada suhu ruang selama 2 jam, kemudian dicuci dengan 0,05\% PBS-Tween 20 sebanyak 4 kali@ 3 menit.

Setelah itu direaksikan dengan antibodi primer dari kambing (antiprolaktin) yang dilarutkan ke dalam blocking buffer BSA $1 \%$ dengan seri pengenceran yaitu $1 / 20,1 / 40$, $1 / 80,1 / 160,1 / 320,1 / 640,1 / 1280,1 / 2560,1 / 5120$ dan $1 /$ 10240 kemudian dimasukkan ke dalam microplate masingmasing $50 \mathrm{ml}$ tiap sumuran, kemudian diinkubasi pada suhu $4^{\circ} \mathrm{C}$ selama semalam, kemudian microplate dicuci dengan 0,05\% PBS-Tween 20 sebanyak $4 \mathrm{X}$

Selanjutnya di coating dengan Antibodi sekunder (Anti Goat IgG Alkaline Phosphatase Conjugated) yang 
dilarutkan dalam TBS Tween-20 dengan pengenceran $1 / 2500$, dimasukkan pada microplate sebanyak $50 \mathrm{ml}$ tiap sumuran, kemudian diinkubasi pada suhu ruang selama 2 jam, kemudian dicuci dengan 0,05\% PBS-Tween 20 sebanyak4kali@3 menit

Setelah itu ditambahkan substrat pNPP dalam diethanolamine $10 \%$, dimasukkan pada microplate sebanyak $50 \mathrm{ml}$ tiap sumuran, selanjutnya diikubasi selama 30 menit pada suhu ruang dan gelap dan jika warna pada kontrol sudah berubah menjadi kuning maka reaksi dihentikan dengan penambahan $\mathrm{NaOH} 3 \mathrm{M}$ (Stop Reaction) sebanyak $50 \mu 1$ tiap sumuran. Setelah itu diukur titer dengan menggunakan ELISA reader dengan panjang gelombang $405 \mathrm{~nm}$. Kontrol dipakai sumuran yang tidak berisikan antigen atau tanpa di-coating dengan isolat prolaktin

\section{HASIL}

Berdasarkan hasil pemeriksaan titer Antiprolaktin dengan uji ELISA indirect diperoleh data kapan mulai terbentuknya antiprolaktin pada kambing untuk pertama kalinya. Titer antibodi dikatakan positif jika mempunyai nilai diatas $2 \times \mathrm{COV}$ (Cut of Value). Nilai COV untuk besar sampel antara 10-100, ditentukan dengan rata-rata kontrol negatif ditambah 2-3 simpangan baku (X + 2-3 SD) (Suwarno dkk., 2003). Data kapan mulai terbentuknya antiprolaktin dapat dilihat pada tabel 2 di bawah ini.

Selanjutnya dilakukan juga penghitungan terhadap ratarata titer antiprolaktin yang terbentuk. Rata-rata titer antiprolaktin pada pengenceran $1 / 160$ yang terbentuk tersebut didapatkan dari 12 kali bleeding (pengambilan darah) pada kambing, yaitu dapat dilihat pada Tabel 3 .

Rerata titer antiprolaktin pada pengenceran 1/160 dari kambing perlakuan dan kontrol pada bleeding ke-1 sampai
Tabel 2. Pembentukan antiprolaktin pada kambing untuk pertama kali

\begin{tabular}{cccc}
\hline Kambing & $\begin{array}{c}\text { Mulai terbentuk antibodi poliklonal antiprolaktin (Anti } \\
\text { prolaktin) pada kambing - pada bleeding ke-1 }\end{array}$ \\
\cline { 2 - 4 } & $\begin{array}{c}\text { Pada pengenceran } \\
\mathbf{1 / 3 2 0} \text { (Titer) }\end{array}$ & $\begin{array}{c}\text { Pada pengenceran } \\
\mathbf{1 / 6 4 0} \text { (Titer) }\end{array}$ & $\mathbf{2} \times$ COV \\
\hline K1 & $0,152^{*}$ & 0,115 & 0,1162 \\
K2 & $0,154^{*}$ & $0,117^{\star}$ & \\
K3 & $0,151^{*}$ & 0,114 & \\
K4 & $0,156^{*}$ & $0,120^{\star}$ & \\
K5 & $0,150^{*}$ & 0,112 & \\
\hline
\end{tabular}

* Titer positif antiprolaktin

ke-12 (profil antiprolaktin) dapat diilustrasikan pada gambar 1 di bawah ini.

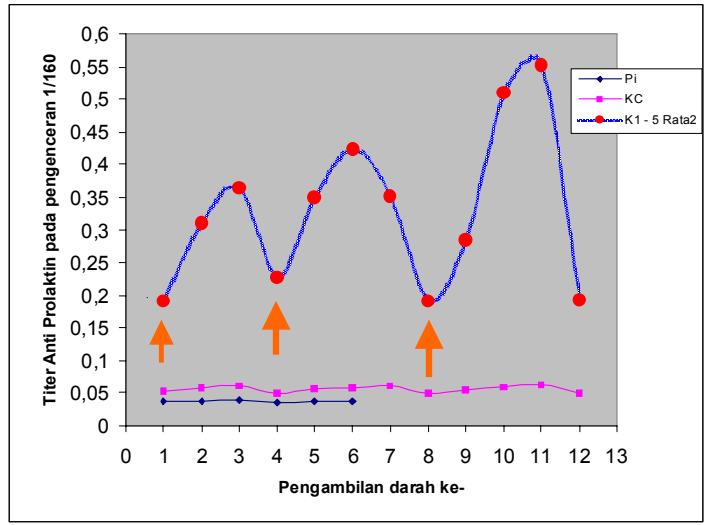

Keterangan: $\uparrow$ dilakukan booster Isolat Prolaktin dalam IFA Pi: Pre imun (bleeding ke-6 sebelum imunisasi) KC: Kambing Kontrol (hanya diimunisasi PBS dalam CFA dan IFA) K1-5 Rata2:Rata-rata titer Antiprolaktin ke-5 ekor Kambing yang diimunisasi isolat prolaktin dalam CFA dan IFA

Gambar 1. Profil Antiprolaktin yang diproduksi pada kambing dari isolat prolaktin

Tabel 3. Rataan Titer Antiprolaktin pengenceran $1 / 160$ dari $12 \times$ bleeding

\begin{tabular}{ccccccccc}
\hline Bleeding ke- & $\mathrm{Pi}(\mathrm{K} 1-6)$ & $\mathrm{KC}$ & $\mathrm{K} 1$ & $\mathrm{~K} 2$ & $\mathrm{~K} 3$ & $\mathrm{~K} 4$ & $\mathrm{~K} 5$ & $\mathrm{~K} 1-5 \mathrm{Rata2}$ \\
\hline 1 & 0,037 & 0,053 & 0,192 & 0,193 & 0,191 & 0,194 & 0,190 & $0,192 \pm 0,001$ \\
2 & 0,038 & 0,058 & 0,311 & 0,313 & 0,310 & 0,312 & 0,309 & $0,311 \pm 0,001$ \\
3 & 0,039 & 0,061 & 0,365 & 0,365 & 0,364 & 0,366 & 0,362 & $0,364 \pm 0,001$ \\
4 & 0,036 & 0,049 & 0,188 & 0,189 & 0,187 & 0,290 & 0,286 & $0,228 \pm 0,005$ \\
5 & 0,038 & 0,055 & 0,350 & 0,352 & 0,348 & 0,351 & 0,349 & $0,350 \pm 0,001$ \\
6 & 0,038 & 0,058 & 0,425 & 0,426 & 0,421 & 0,424 & 0,421 & $0,423 \pm 0,002$ \\
7 & & 0,061 & 0,352 & 0,354 & 0,352 & 0,353 & 0,351 & $0,352 \pm 0,001$ \\
8 & & 0,049 & 0,192 & 0,194 & 0,191 & 0,193 & 0,192 & $0,192 \pm 0,001$ \\
9 & & 0,054 & 0,284 & 0,286 & 0,283 & 0,285 & 0,282 & $0,284 \pm 0,001$ \\
10 & & 0,059 & 0,510 & 0,512 & 0,509 & 0,511 & 0,508 & $0,510 \pm 0,001$ \\
11 & & 0,062 & 0,552 & 0,554 & 0,551 & 0,553 & 0,550 & $0,552 \pm 0,001$ \\
12 & & 0,049 & 0,192 & 0,195 & 0,193 & 0,194 & 0,191 & $0,193 \pm 0,001$ \\
\hline
\end{tabular}

Keterangan: $\mathrm{Pi}$ : Preimun

$\mathrm{KC}$ : Kambing Kontrol

$\mathrm{K} 1-5$ : Kambing nomor $1-5$ 
Berdasarkan uji statistik dengan ANOVA (Analisis of Variant) terdapat perbedaan yang sangat nyata $(\mathrm{p}<0,01)$ diantara perlakuan, tabel 4. Selanjutnya diperlukan uji Student-Newman-Keuls 5\% (SNK) untuk menentukan perlakuan yang paling baik mendapatkan titer Antiprolaktin.

Tabel 4. Rangkuman analisis varian satu arah terhadap titer antiprolaktin

\begin{tabular}{lccccc}
\hline $\begin{array}{c}\text { Sumber } \\
\text { Keragaman }\end{array}$ & Db & JK & KT & F & Sig \\
\hline Perlakuan & 11 & 0,685 & $6,223 \mathrm{E}-02$ & 4,207 &, 000 \\
Galat & 60 & 0,888 & $1,479 \mathrm{E}-02$ & & \\
\hline Total & 71 & 1,572 & & & \\
\hline
\end{tabular}

Berdasarkan uji Student-Newman-Keuls 5\% (tabel 5) diperoleh hasil bahwa perlakuan bleeding ke-11 menghasilkan titer antiprolaktin yang tertinggi yang tidak berbeda nyata dengan bleeding ke-10; bleeding ke-2, 3, 5, 6,7 , dan 9 tidak berbeda nyata dengan bleeding ke-10, sedangkan bleeding ke-1, 4, 8, dan 12 adalah berbeda nyata dengan bleeding ke-11.

Tabel 5. Rerata titer antiprolaktin dari kambing pengenceran $1 / 160$

\begin{tabular}{cccc}
\hline $\begin{array}{c}\text { Perlakuan } \\
\text { (bleeding ke-) }\end{array}$ & N & Rentangan & $\begin{array}{c}\text { Rerata Titer } \\
\text { antiprolaktin }\end{array}$ \\
\hline 1 & 6 & $0,053-0,194$ & $0,16883 \pm 0,05674^{\mathrm{a}}$ \\
2 & 6 & $0,058-0,313$ & $0,26883 \pm 0,1033^{\mathrm{abc}}$ \\
3 & 6 & $0,061-0,366$ & $0,31383 \pm 0,12387^{\mathrm{abc}}$ \\
4 & 6 & $0,049-0,290$ & $0,19617 \pm 0,08799^{\mathrm{a}}$ \\
5 & 6 & $0,055-0,352$ & $0,30083 \pm 0,12044^{\mathrm{abc}}$ \\
6 & 6 & $0,058-0,426$ & $0,3625 \pm 0,14919^{\mathrm{abc}}$ \\
7 & 6 & $0,061-0,354$ & $0,30383 \pm 0,11897^{\mathrm{abc}}$ \\
8 & 6 & $0,049-0,194$ & $0,16850 \pm 0,05855^{\mathrm{a}}$ \\
9 & 6 & $0,054-0,286$ & $0,24567 \pm 0,093908^{\mathrm{abc}}$ \\
10 & 6 & $0,059-0,512$ & $0,43483 \pm 0,18413^{\mathrm{bc}}$ \\
11 & 6 & $0,062-0,554$ & $0,47033 \pm 0,20005^{\mathrm{c}}$ \\
12 & 6 & $0,049-0,195$ & $0,16900 \pm 0,058805^{\mathrm{a}}$ \\
\hline
\end{tabular}

Superskrip berbeda pada kolom yang sama menunjukkan perbedaan bermakna $(p<0,01)$

\section{PEMBAHASAN}

Prolaktin termasuk salah satu hormon reproduksi yang dihasilkan oleh hipofisa anterior. Berdasarkan struktur kimianya, hormon-hormon reproduksi dibagi menjadi tiga katagori, yaitu golongan protein, golongan steroid, dan golongan asam lemak. Hormon prolaktin termasuk golongan hormon protein. Hormon protein termasuk juga peptida, polypeptida dan glycoprotein yang mempunyai BM besar yaitu antara 300-700.000 Dalton (Ismudiono, 1999).

Menurut Jawetz et al. (1991), antibodi adalah protein yang dikenal sebagai imunoglobulin. Antibodi terbentuk sebagai respons terhadap suatu antigen yang bereaksi secara spesifik dengan antigen itu atau sesuatu yang mempunyai hubungan erat dengannya. Antibodi adalah protein khusus, yaitu imunoglobulin-imunoglobulin. Sifat antibodi ini antara lain tergantung pada kelas dari imunoglobulin.

Struktur imunoglobulin terdiri atas fragmen ab $(F a b)$ dan fragmen $\mathrm{c}(F c)$ kedua fragmen ini dirangkai oleh untaian dua sulfida (s-s). Bagian yang terdiri dari asam amino yang bertugas untuk mengikat antigen dikenal dengan side binding antigen, sedang $\mathrm{Fc}$ terdiri atas karbohidrat yang sering berikatan dengan komplemen (Rantam, 2003).

Langkah awal dalam pembentukan antibodi adalah terjadinya fogositosis antigen oleh makrofag. Makrofag ini memberikan antigen kepada sel-sel B dan sel-sel T pembantu. Sel-sel B yang membawa imunoglobulin pada permukaannya yang cocok dengan antigen, dirangsang untuk berproliferasi, membentuk klon dan berdiferensiasi menjadi sel-sel plasma. Sel plasma mensintesis protein antibodi (Vilk, 1992 dan Jawetz et al., 1991).

Pembuatan antiprolaktin ini dilakukan dengan memproduksi serum hiperimun (antiserum) yang mengandung antibodi antiprolaktin, yaitu dilakukan melalui imunisasi terhadap hewan dengan suatu imonogen spesifik. Antibodi didapat dengan jalan mengumpulkan sampel darah dari hewan yang diimunisasi. Antibodi yang didapat dari hiperimunisasi dikenal sebagai antibodi poliklonal (Karnen, 2001; Smith, 1995).

Menurut Smith (1995) faktor-faktor yang terlibat dalam mengoptimalkan respons imun adalah sifat alam imunogen, pelarut, hewan, rute injeksi dan protokol dosis. Polipeptida besar dan protein dengan berat molekul lebih besar dari 5000 Dalton (D) atau 5 Kilo Dalton ( $\mathrm{kDa}$ ) dapat merangsang respons imun yang kuat. Sedangkan Chard (1982) menyebutkan bahwa preparat hormon dengan berat molekul yang besar mempunyai sifat imunogenik sehingga dapat dimanfaatkan sebagai antigen untuk dapat menginduksi timbulnya antibodi spesifik terhadap antigen tersebut. Prolaktin pada unggas merupakan hormon protein dengan berat molekul $24-27 \mathrm{kDa}$, termasuk antigen potensial yang dapat menstimulasi pembentukan antibodi (Fitzgerald, 2004; Agrisera, 2004; Upstate, 2002).

Pelarut Freund lengkap masih dianggap sebagai salah satu dari pelarut paling kuat yang dikenal. Pelarut Freund terdiri atas campuran minyak mineral dan pengemulsi, baik dengan micobakteria (pelarut Freund lengkap) atau tanpa micobakteria (pelarut Freund tidak lengkap). Pelarut Freund lengkap merangsang respons antibodi yang kuat untuk waktu yang lama dangan jalan membebaskan tetes-tetes emulsi secara perlahan dan merangsang fungsi makrofag (Smith, 1995). 
Pemilihan pelarut sangat memengaruhi rute injeksi. Bila menggunakan pelarut yang diserap lambat terutama pelarut minyak seperti Freund, harus diusahakan agar penderitaan hewan dibuat minimum. Dosis imunogen yang dianjurkan untuk kelinci atau hewan coba adalah 50-1000 $\mu$ g per imunisasi (Harlow and Lane, 1988), sedangkan Kerr and Thorpe (1994) menyebutkan dosis yang lebih spesifik untuk kelinci, yaitu 50-250 $\mu \mathrm{g}$ per imunisasi. Menurut Agrisera (2004), dosis imunogen yang dianjurkan untuk kambing adalah $20-500 \mu \mathrm{g}$ per imunisasi, sedangkan menurut Kerr and Thorpe (1994), 250-1000 $\mu \mathrm{g}$ per immunisasi.

Isolat prolaktin yang masuk ke dalam tubuh kambing dianggap sebagai benda asing dan nantinya akan merangsang terbentuknya antibodi yang disebut antiprolaktin. Berdasarkan OD yang diperoleh dari uji ELISA inderect dapat dinyatakan bahwa imunisasi pada kambing dengan menggunakan isolat prolaktin dari serum darah ayam arab fase rontok bulu dapat menyebabkan terbentuknya antiprolaktin (Gambar 1). Perbedaan titer antiprolaktin disebabkan oleh karena adanya perbedaan respons individual dalam menanggapi antigen yang masuk ke dalam tubuh, sesuai dengan pendapat Smith (1995) bahwa respons kambing sangat bervariasi terhadap antigen.

Hasil penelitian ini menunjukkan bahwa pada bleeding ke-4 titer Antiprolaktin sudah mengalami penurunan. Hal tersebut sesuai dengan pendapat Kresno (1996) bahwa pembentukan antibodi tidak berlangsung tanpa batas, ada mekanisme kontrol yang mengendalikan dan menghentikan pembentukan antibodi berlebihan. Titer antibodi pada bleeding ke-5 meningkat lagi setelah dilakukan booster isolat prolaktin dalam IFA ke-2. Hal tersebut dapat terjadi karena adanya respons sekunder. Setelah titer Ab dari respons sekunder menurun maka titer tersebut dapat ditingkatkan lagi setelah diberikan respons sekunder kedua, ketiga dan seterusnya. Hal tersebut dapat terbukti dari penelitian ini, yaitu setelah dilakukan booster yang ketiga dengan isolat prolaktin dalam IFA ke-3 (Gambar 1).

Kesimpulan dari hasil penelitian ini adalah bahwa antiprolaktin dapat dibuat dengan cara melakukan induksi isolat prolaktin yang telah dimurnikan pada kambing lokal jantan dengan cara melakukan imunisasi secara aktif dengan beberapa kali penyuntikan secara intra cutan.

\section{KEPUSTAKAAN}

Allen T, 2002. Information Resources on Induced Molting in Chicken 1902-2002. Animal Welfare Information Center. Email: awic@nal.usda.gov http://www.nal.usda.gov/awic/ Down load: 25 Januari 2004.
Alodan MA, and Mashaly MM, 1999. Effect of Induced Molting in Laying Hens on Production and Immune Parameters. Education and Production. Poultry Science. 78:171-177. Down load: 27 Januari 2004.

Avma HA, 2003. The Animal Welfare and Food Safety Issues Associated with the Forced Molting of Laying Birds. AVMAHurtsAnimals: Vets Without Hearts. United Poultry Concerns, Inc. UPC.online.org. Down load: 20 Pebruari 2004.

Barton J DVM, 2003. Molting. Palm Beach Country Poultry Fanciers Association. Florida. http://www.metimes.com/ issue99-24/eg/chicken.htm.p. 3.

Bedecarrats G, Guemene D, Morvan C, Kuhnlein U, Zadworny D, 1999. Quantification of Prolactin Messenger Ribonucleic Acid, Pituitary Content and Plasma Levels of Prolactin and Detection of Immunoreactive Isoform of Prolactin in Pituitaries from Turkey Embryos during Ontogeny. Biology of Reproduction 61, 757-763. zadworny@agradm.lan.mcgill.ca. Down load: 2 Maret 2004.

Bell and Kuney, 2003. Forced Molting of Laying. Birds. Poultry Organization. p. 8-10. Poultry.org is an educational effort of Farm Sanctuary. Down load: 2 Maret 2004.

Biosystems, 1999. Antibodies: From Design to Assay A Practical Guide. http: //www.pebio.com/pa/340913/html/chapt1.htm. Download: 11 Sept 2004.

Chard T, 1982. An Introduction to RIA and Releted Techniques. $2^{\text {nd }}$ ed. Amsterdam: Elsiver Biomedical Press.

FACT, 2001. Nears Major Food Safety Goal. Chicago IL 60614 (773) 525-4952. PO BOX 14599. Info@FACT.cc.www.fact.cc/se-Main.htm. Down load: 21 April 1004.

Hafez ESE, 2000. Reproduction in Farm Animal. $6^{\text {th }}$ ed. Lea \& Febiger. P, Philadelphia:

Ismudiono, 1999. Fisiologi Reproduksi pada Ternak. Fakultas Kedokteran Hewan. Universitas Airlangga. Surabaya. Hal. 38-42.

Jawezt J, Melnick L, and Adeberg EA, 1991. Mikrobiology untuk Profesi Kesehatan (Review of Medical Microbiology). Edisi 16. Buku Kedokteran EGC, Jakarta, 198-205.

Jabbour HN and Kelly PA, 1997. Prolactin receptor subtypes: a possible mode of tissue spesific Regulation of Prolactin Function. Journals of Reproduction and Fertility; 2, 14-18. Down load: 25 Januari 2004.

Knobil E, Neill D, Ewing LL, Market CL, Greenwald GS, and Pfaff DW, 1988. The Physiologi of Reproduction. Vol. 2. Raven Press, New York, 1379-1385.0.

Kresno SB, 1996. Imunologi: Diagnosis dan Prosedur Laboratorium. Ed. 4. Fakultas Kedokteran Universitas Indonesia. Jakarta, 407-414.

March JB, Sharp PJ, Wilson PW, and Sang HM, 1999. Effect of Active Immunization Against Recombinant-Derived Chicken Prolactin Fusion Protein on the Onset of Broodiness and Photoinduced Egg Laying in Bantam Hens. 
Journal of Reproduction and Fertility; 101:227-233. Down load: 3 April 2004.

Poultry O, 2003. Forced Molting of Laying. Birds. Poultry Organization. p. 1-7. Poultry.org is an Educational Effort of Farm Sanctuary. Down load: 2 Maret 2004.

Ramesh R, Kuenzel WJ, and Proudman JA, 2001. Increased Proliferative Activity and Programmed Cellular Death in the Turkey Hen Pituitary Gland Following Interruption of Incubation Behavior. Regular Article Biology of Reproduction 64, 611-618. Down load: 27 Januari 2004.

Rantam FE, 2003. Metode imunologi. Cetakan 1. Airlangga University Press. Surabaya, 148-162.

Sainsbury D, 1995. Poultry Health and Management; Chicken, Turkey, Ducks, Geese and Quail. 3rd. Ed. University of Cambride. 195.

Smith JR, 1995. Produksi serum hiperimun. Dalam Teknologi ELISA dalam Diagnosis dan Penelitian. James Cook University of North Quensland. GW. Burgess Ed.
Suwarno, Ernawati R, Rahardjo AP, Sianita N, Rahmahani J, Rantam FA, 2003. Prinsip Dasar, Optimalisasi dan Interpretasi Hasil Uji ELISA. Laboratorium Virologi dan Imunologi. Fakultas Kedokteran Hewan. Universitas Airlangga, Surabaya, 1-10.

Vilk WA, 1992. Basic Microbiology $7^{\text {th }}$ ed. Harper Collins Publisher Inc. USA. 276-277.

Webster AB, 1999. Commercial Egg Tip-the Induced Molt: A Critical Control Point for Hazard Minimization of Salmonella Enteritidis Contamination of Eggs. Institute of Agriculture and Natural. Poultry News. Winter 1999. 2-4. http://ianr.www.snl.edu/ianr/asdk/newslet.htm

Yamamoto Wakita M, and Tanaka M, 2003. Tissue Distribution of Prolactin Receptor mRNA during Late Stage Embryogenesis of the Chick. Poultry Science 82: 155-157. Down load: 29 Januari 2004. 